\section{Sanierung vom Geburtshaus: Dachdämmung abgeschlossen!}

Momentan liegt das Röntgen-Geburtshaus vollständig hinter Gerüst und Plane verborgen. Doch dahinter tut sich einiges!

Mitte Mai wurde die Dachdämmung eingeblasen. Was geschieht bei dieser Technik eigentlich und warum wird sie angewendet?

Bei dem eingeblasenen Material handelt es sich um wiederverwertbare Holzwolle, die beim Einblasen verfilzt und somit für Setzungssicherheit sorgt. Zudem bietet das Material eine hohe Wärmespeicherfähigkeit und wirkt feuchteregulierend. Die Hohlräume zwischen den Dachhölzern mit Dämmmatten genau nachzuformen, ist handwerklich praktisch unmöglich. Jeder kleinste Spalt würde Kaltluft unter die Dämmmatten bringen, die sich dort wei- terverbreitet und so ins Haus gelangt. Die eingeblasene Holzwolle passt sich dagegen perfekt den Zwischenräumen an.

Die Technik verhindert zudem ein Verrutschen oder Nachsacken des Materials. Das Haus ist widerstandsfähiger gegen Feuer und gleichzeitig schallisoliert, winddicht und temperaturgeschützt, das Ergebnis ist ein hohlraumfreies und winddichtes Dach: Keine Zug- oder Kaltluft, die durch Ritzen oder Steckdosen eindringen kann.

Die Einblasdämmung hilft beim Energiesparen und senkt die Heizkosten um 20 bis $40 \%$.
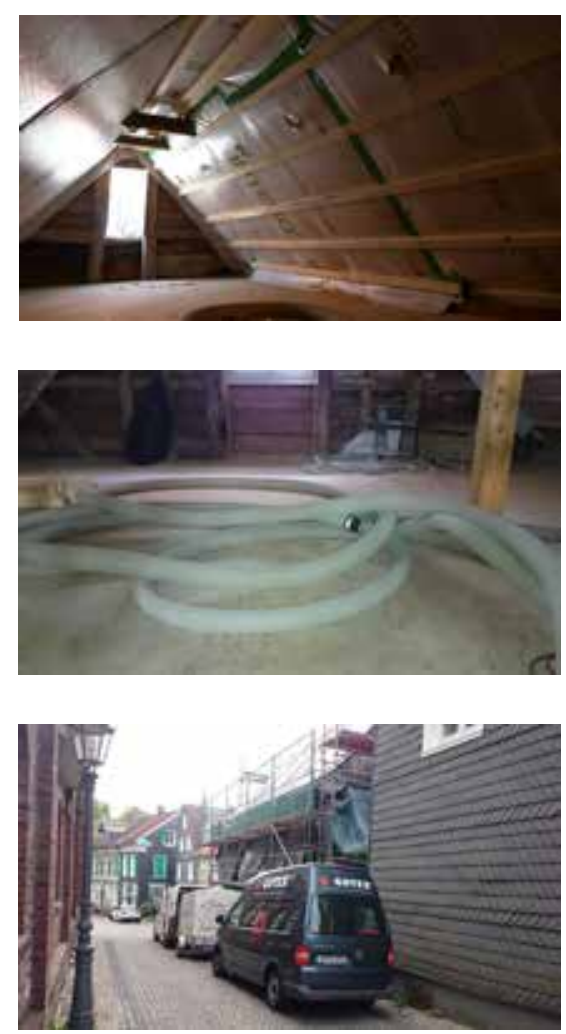
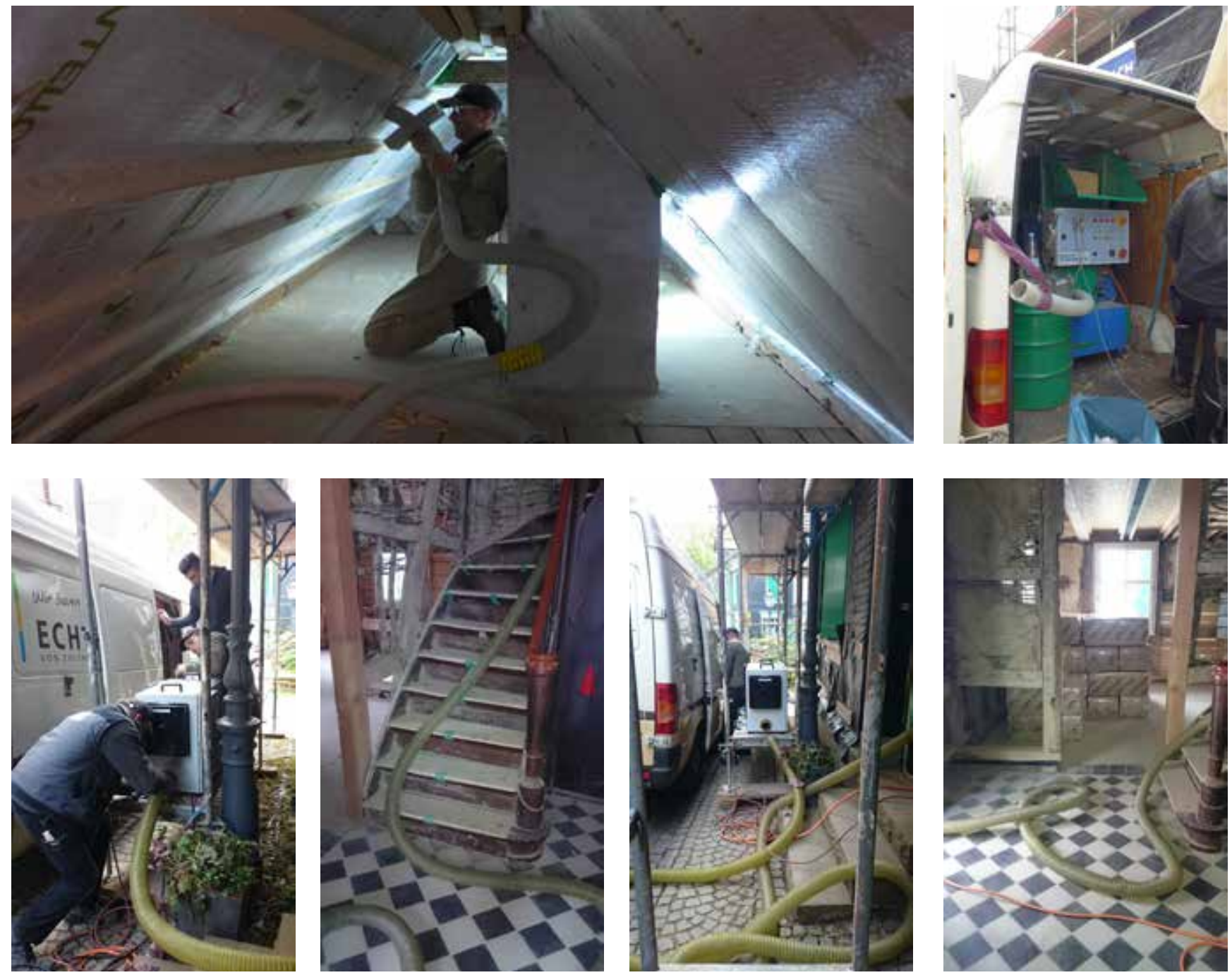